\title{
Phenotypic plasticity of ecotypes across habitats
}

\section{Fatih FAZLIOĞLU}

Ordu Üniversitesi, Faculty of Arts and Sciences, Molecular Biology and Genetics, ORDU

Alınış tarihi: 19 Temmuz 2018, Kabul tarihi: 24 Eylül 2018

Corresponding author: Fatih FAZLIOĞLU, e-posta:fatihfazlioglu@odu.edu.tr

\begin{abstract}
Phenotypic plasticity is the ability of a genotype to produce multiple phenotypes depending on the environmental conditions and it can allow persistence of populations in heterogeneous habitats or under climate change. Therefore, phenotypic plasticity can play a major role in the divergence of populations across habitats. Trade-offs in plant performance in various habitats can give rise to the evolution of specialized ecotypes which are locally adapted (specialized) populations of the same species in distinct environments. According to the specialization hypothesis, specialization of ecotypes to either relatively favorable or unfavorable habitats results in increased or decreased phenotypic plasticity, respectively. The presence of phenotypic plasticity differences among ecotypes can be easily detected by examining their performances at home (native) versus foreign (alien) environments in reciprocal field experiments. In this meta-analysis, I compared phenotypic plasticity of ecotypes specialized in favorable and unfavorable habitats to test the specialization hypothesis by extracting data from 47 empirical studies. Log response ratio (LRR) and plasticity index $\left(\mathrm{PI}_{v}\right)$ were used as effect sizes to detect and quantify significant differences in phenotypic plasticity of ecotypes across habitats. The overall result indicated that it was failed to find an effect of habitat origin on phenotypic plasticity expression of ecotypes. Specialization to either favorable or unfavorable habitats may not alter phenotypic plasticity expression in ecotypes. The interplay between phenotypic plasticity and specialization is quite complex and results of this study may shed light into these two important evolutionary mechanisms in plant ecology which have implications for biodiversity
\end{abstract}

conservation, environmental management, agricultural industry, and ecosystem services.

Key words: ecotypes, meta-analysis, plasticity index, plants

\section{Ekotiplerin farklı habitatlardaki fenotipik plasti- sitesi}

Öz

Fenotipik plastisite, bir genotipin çevresel koşullara bağlı olarak birden fazla fenotip üretebilme yeteneğidir ve popülasyonların heterojen habitatlarda ya da iklimsel değişiklik altında sürekliliğini sağlayabilir. Bu nedenle, fenotipik plastisite habitatlar boyunca popülasyonlar arasındaki ayrımında önemli bir rol oynayabilir. Çeşitli habitatlarda bitkilerin performanslarındaki ödünleşim, özelleşmiş ekotiplerin evrimleşmesine neden olabilir. Ekotipler, aynı türün farklı ortamlarda yerel olarak özelleşmiş popülasyonlarıdır. Özelleşme (specialization) hipotezine göre, ekotiplerin nispeten elverişli ya da elverişsiz habitatlara özelleştirilmesi, fenotipik plastisitenin sırasıyla artmış veya azalmış olmasına neden olur. Ekotipler arasındaki fenotipik plastisite farklılıklar, arazilerde karşılıklı deneylerde evdeki (yerli) ve yabancı (yabancı) ortamlardaki performanslarını inceleyerek kolayca tespit edilebilir. Bu meta-analiz çalışmasında, elverişli ve elverişsiz habitatlarda özelleşmiş ekotiplerin fenotipik plastisitesini, 50 ampirik çalışmadan elde edilen verileri çıkararak özelleşme (specialization) hipotezini test etmek için karşılaştırdım. Ekotiplerin habitatlar boyunca fenotipik plastisitesindeki önemli farklılıkları tespit etmek ve ölçmek için logaritmik yanıt oranı (LRR) ve plastisite indeksi (PIv) etki büyüklükleri olarak kullanılmıştır. Genel sonuç, ekotiplerin fenotipik plastisite ekspres- 
yonu üzerinde habitat kökenli bir etki olmadı̆̆ını göstermiştir. Elverişli ya da elverişsiz habitatlara yönelik özelleşmeler ekotiplerde fenotipik plastisite ekspresyonunu değiştirmedi. Fenotipik plastisite ile özelleşme arasındaki karşılıklı etkileşim oldukça karmaşıktır ve bu çalışmanın sonuçları, bitki ekolojisinde biyoçeşitliliğin korunması, çevre yönetimi, tarımsal sanayi ve ekosistem hizmetlerine etkilleri olan bu iki önemli evrim mekanizmasına ışık tutabilir.

Anahtar kelimeler: ekotipler, meta-analiz, plastisite indeksi, bitkiler

\section{Introduction}

Ecotypes are locally adapted (specialized) populations of the same species in distinct environments (McGraw and Antonovics, 1983; Gauthier et al., 1998; de Jong, 2005; Bennington et al., 2012). Evolution of ecotypes can be shaped by selective forces depending on features of the environment such as microclimate (e.g., temperature, rainfall, moisture, and growing season length), soil conditions (e.g., productivity, texture, and salinity), abiotic stress (e.g., heavy metals and acidity), topography (e.g., altitude, aspect, and photoperiod), biotic interactions (e.g., facilitation, competition, herbivory, and pollinators), and latitude (Bennington and McGraw, 1995; Conover and Schultz, 1995). As a result of these distinct environmental conditions, ecotypic differentiation can be observed between populations across habitats. Ecotypic differentiation (and genetic divergence eventually) can be either reinforced by the selection or conversely be impeded by gene flow between populations (Lenormand, 2002).

Formation of ecotypes can be affected by low gene flow, environmental conditions, and the interaction of the environment by genotype that is called phenotypic plasticity (de Jong 2005). Phenotypic plasticity is the ability of a genotype to produce multiple phenotypes depending on the environmental conditions and can allow persistence of an individual (and populations) in heterogeneous habitats or under environmental change (Pigliucci, 2001; Sultan, 1995, 2000; Nicotra et al., 2010). Phenotypic plasticity can play a major role in divergence between populations (Pfennig et al., 2010). Although phenotypic plasticity is a trait-level response of genotypes, it is possible to compare the plasticity of genotypes, populations, and species (e.g., Valladares et al., 2000; Richards et al., 2006; Ghalambor et al., 2007; Griffith and Sultan
2012; Godoy et al., 2011; Forsman 2015; Hollander et al., 2015).

In favorable (benign or high resource) habitats, plants tend to take advantage of abundant resources and express higher performance (e.g., higher values in fitness traits) than the ancestral genotypes. However, in relatively unfavorable (harsh or resourcepoor) habitats, ecotypes from favorable habitats tend to express lower performance than the ancestral genotypes (i.e., specialization hypothesis - Lortie and Aarssen, 1996) because the traits associated with high resource acquisition would be maladaptive and costly in resource-poor environments where investment in stress tolerance traits (e.g., nutrient retention and defense structures) should be prioritized (Lambers and Poorter, 1992). Allocation of limited resources into various traits and trade-offs in performance across habitats can give rise to the evolution of specialized ecotypes (Futuyma and Moreno, 1988; Kawecki and Ebert, 2004).

Reciprocal transplant experiments are an ideal method to separately test the effects of genetics, environment, and phenotypic plasticity (Langlet, 1971). The presence of differences among ecotypes can be easily detected by examining their performances at home (native) versus foreign (alien) environments. However, transplanting populations across different habitats and running long field experiments over several years tend not to be very practical. Therefore, there are a limited number of reciprocal transplant experiments in the literature.

In this meta-analysis, I compared phenotypic plasticity of ecotypes specialized in favorable and unfavorable habitats by extracting data from reciprocal transplant experiments conducted in field to test the specialization hypothesis at the population level (Lortie and Aarssen, 1996). Specifically, I asked the following question: Do ecotypes from favorable habitats express greater plasticity than those specialized in unfavorable habitats?

\section{Methods}

Data were collected from databases such as ISI Web of Knowledge and Scopus in 2017, using the keywords 'reciprocal experiment', 'transplant', 'field' and 'plants'. Different combinations of these keywords were used and reference sections of the selected studies were also checked to find the most relevant studies. Epiphytes, aquatic plants, shrubs, and trees were excluded and only studies with terrestrial herbaceous plant species conducted in field conditions were included in this meta-analysis. 
Only one performance trait was included from each species to prevent pseudo-replication and sampling bias. Ecotypes were categorized as either from favorable (e.g., low altitude, mesic area, sunny environment) or unfavorable habitats (e.g., high altitude, xeric area, and shade environment). Traits were also categorized as either size (e.g., biomass and growth rate) or fitness (e.g., number or biomass of seeds or fruits). Biomass trait is a measure of size that can be associated with resource acquisition of an individual; whereas seed trait is a more direct measure of fitness and performance. Therefore, the trait type can be important to interpret plant responses more specifically. Treatment types of experiments (e.g., altitude, nutrient, light, latitude, and water) were also recorded. In total, I extracted performance traits data from tables and figures of 47 empirical studies with the help of measuring tool in PDF-XChange Editor software (see Appendix A and B for the complete list of studies and extracted data).

I used the log response ratio (LRR) which is widely used in meta-analysis studies as a common effect size to analyze the phenotypic plasticity of ecotypes across habitats:

LRR = Log (Xa / Xh)

where Xa is trait mean away; $\mathrm{Xh}$ is trait mean at home.

Plasticity Index (PIv) was also used to quantify the phenotypic plasticity (Valladares et al., 2000):

$\mathrm{PIv}=[\mathrm{Max}(\mathrm{Xa}, \mathrm{Xh})-\mathrm{Min}(\mathrm{Xa}, \mathrm{Xh})] / \operatorname{Max}(\mathrm{Xa}, \mathrm{Xh})$

where $\mathrm{Xa}$ is trait mean away; $\mathrm{Xh}$ is trait mean at home.

PIV has been widely used to compare phenotypic plasticity across populations because it is a simple and powerful index indicating the overall absolute change in trait means (Balaguer et al., 2001; Godoy et al., 2011; Gratani et al., 2012; Valladares et al., 2006) and the result is always between 0 and 1 (no plasticity and maximum plasticity, respectively). One-way ANOVA tests and general linear model (GLM) were applied using JMP version 13.2 (SAS Institute, NC, USA). Graphs were prepared using SigmaPlot software v.12.5 (Systat Software Inc., CA, USA).

\section{Results}

There were no differences between phenotypic plasticity of ecotypes from favorable versus unfavorable habitats (Fig. 1 and Table 1). Therefore, it was failed to find an effect of the habitat origin on the expression of phenotypic plasticity across ecotypes.
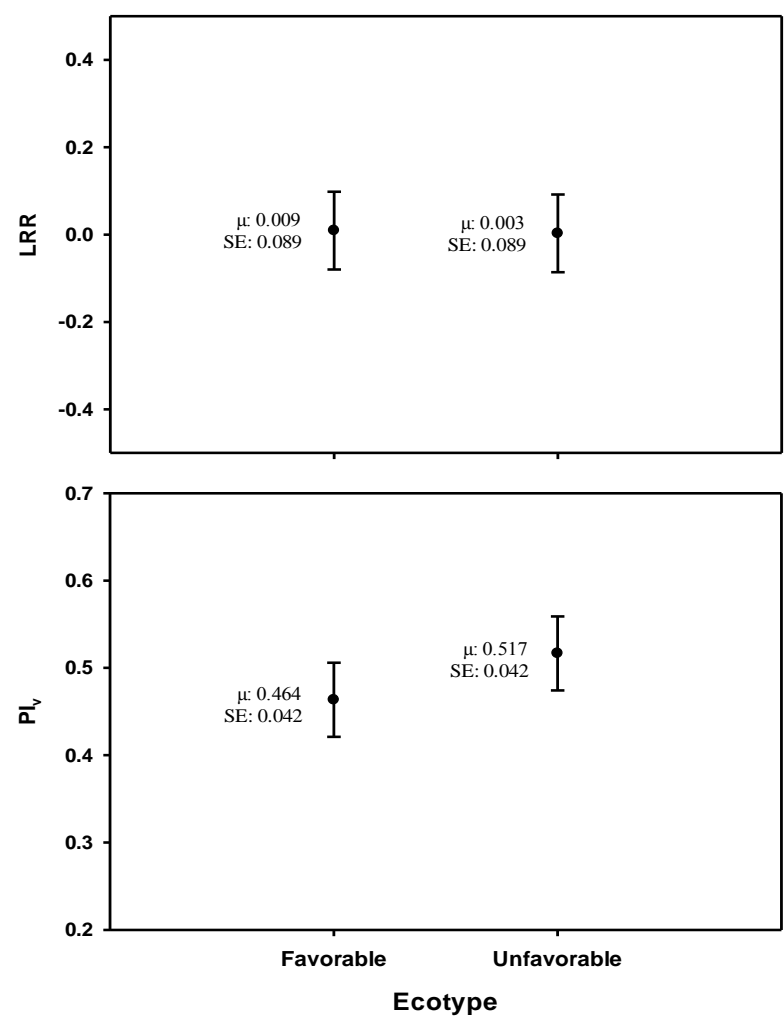

Figure 1. Phenotypic plasticity of ecotypes from favorable and unfavorable habitats in terms of log response ratio (LRR) and plasticity index (PIv). $\mu$ and SE represent mean and standard error, respectively.

A general linear model (GLM) was constructed to detect effects of the habitat of origin, trait types, treatment types of experiments and interactions of these factors on phenotypic plasticity of ecotypes (Table 2).

\section{Discussion}

According to the overall result of 47 reciprocal field studies, it was failed to find an effect of habitat origin on phenotypic plasticity expression of ecotypes. Therefore, specialization of ecotypes to either favorable or unfavorable habitats may not alter phenotypic plasticity expression (Table 1 and Figure 1). This result did not support the specialization hypothesis (Lortie and Aarssen, 1996) which was in agreement with previous studies (Fazlioglu and Bonser 2016; Fazlioglu et al., 2017). However, in this study, only the magnitude of plasticity was tested but not the direction of plasticity (i.e., increase or decrease in trait values) that can reveal whether it is adaptive or maladaptive. 
Table 1. One-way ANOVA test results indicating differences between phenotypic plasticity of ecotypes from favorable and unfavorable habitats in terms of PIv and LRR. DF and Prob. stand for degrees of freedom and probability, respectively.

\begin{tabular}{|c|c|c|c|c|c|c|c|}
\hline $\mathrm{X}$ & $\mathrm{Y}$ & Source & DF & Sum of Squares & Mean Square & F Ratio & Prob. $>$ F \\
\hline \multirow{6}{*}{ Ecotype } & \multirow{3}{*}{$\mathrm{PI}_{\mathrm{v}}$} & Ecotype & 1 & 0.069 & 0.069 & \multirow{3}{*}{0.782} & \multirow{3}{*}{0.38} \\
\hline & & Error & 96 & 8.479 & 0.088 & & \\
\hline & & C. Total & 97 & 8.548 & & & \\
\hline & \multirow{3}{*}{ LRR } & Ecotype & 1 & 0.001 & 0.001 & \multirow{3}{*}{0.003} & \multirow{3}{*}{0.96} \\
\hline & & Error & 96 & 37.224 & 0.388 & & \\
\hline & & C. Total & 97 & 37.225 & & & \\
\hline
\end{tabular}

Table 2. Results of the general linear model consisting effects of habitat, trait, treatment and their interactions on phenotypic plasticity of ecotypes. DF and Prob. stand for degrees of freedom and probability, respectively

\begin{tabular}{|c|c|c|c|c|c|c|c|}
\hline \multirow[b]{2}{*}{ Source } & \multirow[b]{2}{*}{ DF } & \multicolumn{3}{|c|}{$\mathrm{PI}_{\mathrm{v}}$} & \multicolumn{3}{|c|}{ LRR } \\
\hline & & $\begin{array}{c}\text { Sum of } \\
\text { Squares }\end{array}$ & F Ratio & Prob. $>\mathrm{F}$ & $\begin{array}{c}\text { Sum of } \\
\text { Squares }\end{array}$ & F Ratio & Prob. > F \\
\hline Ecotype & 1 & 0.004 & 0.040 & 0.84 & 0.029 & 0.070 & 0.79 \\
\hline Trait & 1 & 0.212 & 2.145 & 0.15 & 0.014 & 0.034 & 0.85 \\
\hline Treatment & 4 & 0.230 & 0.583 & 0.68 & 0.230 & 0.141 & 0.97 \\
\hline Ecotype $\times$ Trait & 1 & 0.001 & 0.007 & 0.93 & 0.634 & 1.546 & 0.22 \\
\hline Ecotype $\times$ Treatment & 4 & 0.086 & 0.217 & 0.93 & 1.491 & 0.910 & 0.46 \\
\hline Trait $\times$ Treatment & 4 & 0.042 & 0.106 & 0.98 & 0.197 & 0.120 & 0.98 \\
\hline Ecotype $\times$ Trait $\times$ Treatment & 4 & 0.044 & 0.111 & 0.98 & 2.012 & 1.227 & 0.31 \\
\hline
\end{tabular}

Effects of different trait types (size or fitness related), treatment types (altitude, nutrient, light, latitude, water) and their interactions also did not affect the results of this meta-analysis (Table 2). Therefore, lack of significant difference between phenotypic plasticity of ecotypes was not due to different factors such as the trait type or treatment used in reciprocal experiments. Although phenotypic plasticity is predicted to be decreased under stressful conditions (Valladares et al., 2007), this meta-analysis did not detect such a trend. However, a decreased plasticity in fitness traits is advantageous because it would suggest that fitness does not change across various habitats such as in jack-of-all-trades strategy (Richards et al., 2006). Reduced phenotypic plasticity in performance traits may be common in homogeneous habitats (Griffith and Sultan, 2005; Avramov and Tucic, 2006).

According to the specialization hypothesis (Lortie and Aarssen, 1996), phenotypic plasticity is a byproduct of the natural selection. After specialization to an environment, an individual may perform only well in that specific environment and may fail in a different one (Via, 1993). Moreover, limits and costs of phenotypic plasticity (Dewitt et al., 1998; Weinig et al., 2006) may restrict the occurrence of plasticity in nature (van Tienderen, 1991; van Kleunen and
Fischer, 2005). Genetic variance in a genotype (which is necessary for specialization to occur) can also affect the evolution of phenotypic plasticity and specialization because less genetic variance might be associated with less plasticity (Berg et al., 2005; Magi et al., 2011; Chevin and Hoffmann, 2017). Moreover, phenotypic plasticity may conceal the effect of specialization by buffering against natural selection (Frei et al., 2014; Lazaro-Nogal et al., 2016). Therefore, a variety of ecotype responses in this metaanalysis might be explained by the degree of specialization, genetic variance, and phenotypic plasticity costs across habitats.

Anthropogenic changes in our habitats have been affecting our ecosystems and response of sessile species such as plants to these environmental fluctuations has far-reaching implications. The result of this study may provide insight into phenotypic plasticity and specialization patterns in ecotypes across favorable and unfavorable habitats. Understanding general trends of these two evolutionary mechanisms (phenotypic plasticity and specialization) in plants is important in terms of biodiversity conservation, environmental management, agricultural industry, and ecosystem services because the survival of plant species in new environmental conditions can be at risk due to current climate change. 


\section{Acknowledgments}

I would like to thank Assoc. Prof. Stephen Bonser and Dr. Justin S. H. Wan for their contributions.

\section{References}

Avramov, S., Tucic, B., 2006. Plasticity to an irradiance gradient in foliage attributes of a perennial monocot Iris pumila (L.): Comparison of populations from habitats of contrasting light conditions. Polish Journal of Ecology, 54(3): 403-416.

Balaguer, L., Martínez-Ferri, E., Valladares, F., Pérez-Corona, M. E., Baquedano, F. J., Castillo, F. J., Manrique, E., 2001. Population divergence in the plasticity of the response of Quercus coccifera to the light environment. Functional Ecology, 15(1):124135.

Bennington, C. C., McGraw, J. B., 1995. Natural selection and ecotypic differentiation in Impatiens pallida. Ecological Monographs, 65(3): 303-323.

Bennington, C. C., Fetcher, N., Vavrek, M. C., Shaver, G. R., Cummings, K. J., McGraw, J. B., 2012. Home site advantage in two long-lived arctic plant species: Results from two 30-year reciprocal transplant studies. Journal of Ecology, 100(4): 841-851.

Berg, H., Becker, U., Matthies, D., 2005. Phenotypic plasticity in Carlina vulgaris: effects of geographical origin, population size, and population isolation. Oecologia, 143(2): 220-231.

Chevin, L. M., Hoffmann, A. A., 2017. Evolution of phenotypic plasticity in extreme environments. Philosophical Transactions of the Royal Society B: Biological Sciences, 372(1723): 20160138.

Conover, D. O., Schultz, E. T., 1995. Phenotypic similarity and the evolutionary significance of countergradient variation. Trends in Ecology \& Evolution, 10(6): 248-252.

de Jong, G., 2005. Evolution of phenotypic plasticity: patterns of plasticity and the emergence of ecotypes. New Phytologist, 166(1): 101-117.

Dewitt, T. J., Sih, A., Wilson, D. S., 1998. Costs and limits of phenotypic plasticity. Trends in Ecology \& Evolution, 13(2): 77-81.

Fazlioglu, F., Bonser, S. P., 2016. Phenotypic plasticity and specialization in clonal versus non-clonal plants: A data synthesis. Acta Oecologica, 77: 193-200.

Fazlioglu, F., Wan, J. S. H., Bonser, S. P., 2017. Testing specialization hypothesis on a stress gradient. Austral Ecology, 42(1): 40-47.

Forsman, A., 2015. Rethinking phenotypic plasticity and its consequences for individuals, populations and species. Heredity, 115(4): 276-284.
Frei, E. R., Ghazoul, J., Pluess, A. R., 2014. Plastic responses to elevated temperature in low and high elevation populations of three grassland species. PLoS ONE, 9(6): e98677.

Futuyma, D. J., Moreno, G., 1988. The evolution of ecological specialization. Annual Review of Ecology, Evolution, and Systematics, 19(1): 207-233.

Gauthier, P., Lumaret, R., Bedecarrats, A., 1998. Ecotype differentiation and coexistence of two parapatric tetraploid subspecies of cocksfoot (Dactylis glomerata) in the Alps. New Phytologist, 139(4): 741750.

Ghalambor, C. K., Mckay, J. K., Carroll, S. P., Reznick, D. N., 2007. Adaptive versus non-adaptive phenotypic plasticity and the potential for contemporary adaptation in new environments. Functional Ecology, 21(3): 394-407.

Godoy, O., Valladares, F., Castro-Díez, P., 2011. Multispecies comparison reveals that invasive and native plants differ in their traits but not in their plasticity. Functional Ecology, 25(6):1248-1259.

Gratani, L., Catoni, R., Pirone, G., Frattaroli, A. R., Varone, L., 2012. Physiological and morphological leaf trait variations in two Apennine plant species in response to different altitudes. Photosynthetica, 50(1): 15-23.

Griffith, T., Sultan, S. E., 2005. Shade tolerance plasticity in response to neutral vs green shade cues in Polygonum species of contrasting ecological breadth. New Phytologist, 166(1): 141-147.

Griffith, T., Sultan, S. E. 2012. Field-based insights to the evolution of specialization: plasticity and fitness across habitats in a specialist/generalist species pair. Ecology and Evolution, 2(4): 778-791.

Hollander, J., Snell-Rood, E., Foster, S. 2015. New frontiers in phenotypic plasticity and evolution. Heredity, 115(4): 273-275.

Kawecki, T. J., Ebert, D., 2004. Conceptual issues in local adaptation. Ecology Letters, 7(12): 1225-1241.

Lambers, H., Poorter, H., 1992. Inherent variation in growth rate between higher plants: A search for physiological causes and ecological consequences. Advances in Ecological Research, 23: 188-261.

Langlet, 0., 1971. The hundred years of genecology. Taxon, 20(5/6): 656-722.

Lazaro-Nogal, A., Matesanz, S., Hallik, L., Krasnova, A., Traveset, A., Valladares, F., 2016. Population differentiation in a Mediterranean relict shrub: the potential role of local adaptation for coping with climate change. Oecologia, 180(4): 1075-1090. 
Lenormand, T., 2002. Gene flow and the limits to natural selection. Trends in Ecology and Evolution, 17(4): 183-189.

Lortie, C., Aarssen, L. W., 1996. The specialization hypothesis for phenotypic plasticity in plants. International Journal of Plant Sciences, 157(4): 484-487.

Magi, M., Semchenko, M., Kalamees, R., Zobel, K., 2011. Limited phenotypic plasticity in range-edge populations: a comparison of co-occurring populations of two Agrimonia species with different geographical distribution. Plant Biology, 13(1): 177-184.

McGraw, J. B., Antonovics, J., 1983. Experimental ecology of Dryas octopetala ecotypes. I. Ecotypic differentiation and life-cycle stages of selection. Journal of Ecology, 71(3): 879-897.

Nicotra, A. B., Atkin, O. K., Bonser, S. P., Davidson, A. M., Finnegan, E. J., Mathesius, U., Poot, P., Purugganan, M. D., Richards, C. L., Valladares, F., van Kleunen, M., 2010. Plant phenotypic plasticity in a changing climate. Trends in Plant Science, 15(12): 684-692.

Pfennig, D. W., Wund, M. A., Snell-Rood, E. C., Cruickshank, T., Schlichting, C. D., Moczek, A. P., 2010. Phenotypic plasticity's impacts on diversification and speciation. Trends in Ecology \& Evolution, 25(8): 459467.

Pigliucci, M., 2001. Phenotypic plasticity: beyond nature and nurture, The John Hopkins University Press. Baltimore, USA. 328 pp.

Richards, C. L., Bossdorf, O., Muth, N. Z., Gurevitch, J., Pigliucci, M., 2006. Jack of all trades, master of some? On the role of phenotypic plasticity in plant invasions. Ecology Letters, 9(8): 981-993.
Sultan, S. E., 1995. Phenotypic plasticity and plant adaptation. Acta Botanica Neerlandica, 44(4): 363-383.

Sultan, S. E., 2000. Phenotypic plasticity for plant development, function and life history. Trends in Plant Science, 5(12): 537-542.

Valladares, F., Wright, S. J., Lasso, E., Kitajima, K., Pearcy, R. W., 2000. Plastic phenotypic response to light of 16 congeneric shrubs from a Panamanian rainforest. Ecology, 81(7): 1925-1936.

Valladares, F., Sanchez-Gomez, D., Zavala, M. A., 2006. Quantitative estimation of phenotypic plasticity: Bridging the gap between the evolutionary concept and its ecological applications. Journal of Ecology, 94(6): 1103-1116.

Valladares, F., Gianoli, E., Gomez, J. M., 2007. Ecological limits to plant phenotypic plasticity. The New Phytologist, 176(4): 749-763.

van Kleunen, M., Fischer, M., 2005. Constraints on the evolution of adaptive phenotypic plasticity in plants. The New Phytologist, 166(1): 49-60.

van Tienderen, P. H., 1991. Evolution of generalists and specialist in spatially heterogeneous environments. Evolution, 45(6): 1317-1331.

Via, S., 1993. Adaptive phenotypic plasticity: target or byproduct of selection in a variable environment? The American Naturalist, 142(2): 352-365.

Weinig, C., Johnston, J., German, Z. M., Demink, L. M., 2006. Local and global costs of adaptive plasticity to density in Arabidopsis thaliana. The American Naturalist, 167(6): 826-836. 